\title{
THE HIV/AIDS EPIDEMIOLOGICAL SITUATION AMONG MEN AND WOMEN IN SERBIA IN THE PERIOD 2007-2017: JOINPOINT REGRESSION ANALYSIS
}

\author{
Aleksandra Nikolić ${ }^{1}$ Ana Božić ${ }^{2}$, Danijela Simić3 ${ }^{3}$ Sandra Šipetić Grujičić \\ Institut za epidemiologiju, Medicinski fakultet Univerziteta u \\ Beogradu, Beograd, Srbija \\ 2 Medicinski fakultet Univerziteta u Beogradu, Beograd, Srbija \\ 3 Institut za javno zdravlje Srbije „Dr Milan Jovanović Batut” \\ Institute of Epidemiology, Faculty of Medicine, University of \\ Belgrade, Belgrade, Serbia \\ 2 Faculty of Medicine, University of Belgrade, Belgrade, Serbia \\ 3 Institute of Public Health of Serbia "Dr Milan Jovanović Batut"
}

\section{SAŽETAK}

Uvod: U svetu, prema podacima za 2018. godinu, HIV/AIDS (engl. Human Immunodeficiency Virus - HIV/Acquired Immunodeficiency Syndrome - AIDS) predstavlja veliki javnozdravstveni problem jer oko 37,9 miliona ljudi živi sa HIV/AIDS-om, a broj umrlih usled bolesti i stanja povezanih sa AIDS-om je oko 770.000 .

Cilj: Cilj rada je bio da se analizira kretanje novodijagnostikovanih inficiranih HIV-om i obolelih i umrlih od AIDS-a među muškarcima i ženama u Srbiji za period 2007 - 2017. godine.

Materijal i metode: Podaci o novodijagnostikovanim osobama pozitivnim na HIV, obolelima i umrlima od AIDS-a, preuzeti su iz Izveštaja o zaraznim bolestima u Republici Srbiji. Na osnovu dobijenih podataka izračunate su uzrasno-specifične i standardizovane stope (standardizovane prema populaciji sveta incidencije i mortaliteta). Za ispitivanje trenda je korišćena joinpoint regresiona analiza.

Rezultati: Prosečne standardizovane stope novodijagnostikovanih osoba inficiranih HIV-om (na 100.000) u Srbiji, za period 2007 - 2017, bile su 3,4 za muškarce i 0,8 za žene. Kod muškaraca je prisutan značajan godišnji porast standardizovanih stopa novodijagnostikovanih osoba inficiranih HIV-om od 7\%, a kod žena od 21,1\%. Prosečne standardizovane stope (na 100.000) incidencije AIDS-a bile su 0,9 za muškarce i 0,2 za žene. Prisutan je značajan godišnji porast standardizovane stope incidencije AIDS-a kod muškaraca od 4,9\%, a značajan pad od - $12,2 \%$ kod žena. Prosečne standardizovane stope mortaliteta od AIDS-a (na 100.000) bile su 0,4 za muškarce i 0,1 za žene. U posmatranom periodu nema značajnih promena standardizovanih stopa mortaliteta od AIDS-a kod muškaraca, dok je kod žena prisutan značajan pad od $-13,9 \%$ godišnje. Najč̌šći put prenosa HIV infekcije kod muškaraca bio je seksualni odnos sa muškarcima (69,0\%), a kod žena heteroseksualni odnos (75,7\%).

Zaključak: Potrebno je dalje raditi na unapređenju preventivnih mera, posebno edukaciji mladih o putevima prenošenja i rizicima, kao i na ranom otkrivanju osoba inficiranih HIV-om i pravovremenom lečenju.

Ključne reči: HIV, AIDS, joinpoint regresiona analiza, trend

Autor za korespondenciju:

Sandra Šipetić Grujičić

Institut za epidemiologiju, Medicinski fakultet Univerziteta u Beogradu

Višegradska 26 a, 11000 Beograd, Srbija

Elektronska adresa: sandra.grujicic2014@gmail.com

Primljen • Received: June 21, 2020; Revidiran - Revised: Jul 13, 2020;

\begin{abstract}
Introduction:Human ImmunodeficiencyVirus(HIV)/Acquired Immunodeficiency Syndrome (AIDS) is a global major health problem. According to the data for 2018, there were 37.9 million people living with HIV/AIDS in the world, and the number of deaths related to AIDS was about 770,000 .

Aim: The aim of this study was to analyze the trend of newly diagnosed HIVinfected people, AIDS patients and AIDS-related deaths among men and women in Serbia, for the period 2007-2017.
\end{abstract}

Materials and methods: Data on newly diagnosed HIV-infected people, AIDS patients and AIDS-related deaths were taken from the Report on Infectious Diseases in the Republic of Serbia. Age-specific and standardized mortality and incidence rates (standardized according to the world population) were calculated based on the data obtained. Joinpoint regression analysis was used to examine the trend.

Results: The average standardized rates of newly diagnosed HIV-infected people (per 100,000) in Serbia, for the period 2007-2017, were 3.4 for men and 0.8 for women. There was a significant annual increase in standardized rates of newly diagnosed HIV-infected people; $7.0 \%$ for men and $21.1 \%$ for women. The average standardized rates (per 100,000) of AIDS incidence were 0.9 for men and 0.2 for women. There was a significant annual increase of $4.9 \%$ in the standardized incidence rate of AIDS in men, and a significant decrease of $-12.2 \%$ in women. The average standardized mortality rates from AIDS (per 100,000) were 0.4 for men and 0.1 for women. During the observation period, there were no significant changes in the standardized mortality rates from AIDS in men, while in women there was a significant decline of $-13.9 \%$ per year. The most common route of HIV transmission in men was sexual intercourse with men (69.0\%), and in women it was heterosexual intercourse (75.7\%).

Conclusion: Further work is needed, primarily in advancing preventive measures, particularly by educating young people about transmission pathways and risks, but also in the early detection of HIV-infected persons and timely treatment.

Keywords: HIV, AIDS, joinpoint regression analysis, trend

\section{Corresponding author:}

Sandra Šipetić Grujičić

Institute of Epidemiology, Faculty of Medicine, University of Belgrade

26 a Višegradska street, 11000 Belgrade, Serbia

E-mail: sandra.grujicic2014@gmail.com 


\section{UVOD}

Infekcija virusom humane imunodeficijencije (engl. Human Immunodeficiency Virus - HIV) i dalje predstavlja jedan od vodećih javnozdravstvenih izazova u svim zemljama sveta. Takođe, veliki problem predstavlja i sindrom stečene imunodeficijencije (engl. Acquired Immunodeficiency Syndrome - AIDS), poslednji i najteži stadijum HIV infekcije, koji se razvija posle sedam do deset godina, ukoliko se infekcija ne leči.

Procenjuje se da je u svetu oko 37,9 miliona ljudi živelo sa HIV/AIDS-om u 2018. godini, dok je broj umrlih usled bolesti i stanja povezanih sa AIDS-om bio 770.000. Poslednjih decenija veliki napori se ulažu u okončanje epidemije HIV/AIDS-a, koja je zvanično započela pre nešto više od trideset i osam godina. Prema globalnoj strategiji Zajedničkog programa Ujedinjenih nacija za HIV i AIDS (engl. United Nations Programme on HIV/AIDS - UNAIDS) "90-90-90“, bilo je planirano da do 2020. godine $90 \%$ ljudi koji žive sa HIV-om poznaje svoj pozitivan status na HIV, da je $90 \%$ ljudi koji znaju svoj pozitivan status na HIV na antiretrovirusnoj (ARV) terapiji, i da $90 \%$ ljudi koji su na ARV terapiji ima stabilnu virusnu supresiju [1]. Na globalnom nivou dolazi do opadanja broja novoinficiranih HIV-om za 16\% tokom poslednjih osam godina. Međutim, i pored toga, svet je daleko od realizacije cilja da do 2020. godine broj osoba novoinficiranih HIV-om bude manji od 500.000 [2].

U 2018. godini je više od polovine (54\%) novoinficiranih HIV-om, uzrasta 15 - 49 godina, bilo među ključnim populacijama i njihovim partnerima - 18\% među klijentima seksualnih radnika/radnica i seksualnim partnerima drugih ključnih populacija; $17 \%$ među muškarcima koji imaju seksualni odnos sa muškarcima (engl. men who have sex with men - MSM); $12 \%$ među osobama koje injektiraju droge; $6 \%$ među seksualnim radnicima/radnicama, a $46 \%$ iz opšte populacije [2]. U regionima sa visokom prevalencijom HIV infekcije, kao što su istočna i južna Afrika, HIV se pretežno javljao kod osoba iz opšte populacije, a u regionima sa nižom prevalencijom među osobama iz ključnih populacija i njihovim seksualnim partnerima.

Zabrinjava procena da u svetu značajan broj osoba pozitivnih na HIV ne zna da je inficirano HIV-om, pri čemu se taj procenat kreće od 30 do $50 \%$ u regionu Evrope. U periodu od 1984. do kraja 2017. godine u Republici Srbiji registrovane su 3.664 osobe inficirane HIV-om, od kojih je 1.901 osoba obolela od AIDS-a, a 1.110 osoba je umrlo od AIDS-a. Procene UNAIDS-a i Svetske zdravstvene organizacije (SZO) ukazuju da je krajem 2018. godine u Srbiji 3.000 (2.200 - 3.800) osoba živelo sa HIV-om, od kojih 400 do 1.200 osoba nije znalo da je inficirano HIV-om [3].

Sve navedeno ukazuje da je, uprkos brojnim novim saznanjima iz virusologije, farmakologije, intenzivnog

\section{INTRODUCTION}

Infection with the Human Immunodeficiency Virus (HIV) remains one of the leading public health challenges in all of the countries in the world. Also, acquired immunodeficiency syndrome (AIDS) constitutes a great problem as the last and most severe stage of HIV infection, which develops within 7 to 10 years, if the infection is left untreated.

The estimation is that, in 2018, around 37.9 million people were living with HIV/AIDS worldwide, while 770,000 died as the result of AIDS-related diseases and conditions. In the previous decades, great efforts have been made to end the HIV/AIDS epidemic, which officially started a little over 38 years ago. According to the global 90-90-90 strategy of the United Nations Programme on HIV/AIDS - UNAIDS, it was planned that, by the year $2020,90 \%$ of people living with HIV would be aware of their HIV positive status, that $90 \%$ of the people aware of their HIV positive status would be on antiretroviral (ARV) therapy, and that $90 \%$ of those on ARV therapy would have stable viral suppression [1]. Globally, in the previous 8 years, there has been a 16\% decrease in the number of newly infected HIV patients. Nevertheless, the world is still far from achieving the goal set for 2020 , i.e. reducing the number of people newly infected with HIV below 500,000 [2].

In 2018, more than half (54\%) of people newly infected with HIV, aged 15 - 49 were amongst the key populations and their partners - $18 \%$ were sex worker clients and sexual partners of other key groups; $17 \%$ were men who have sex with men (MSM); $12 \%$ were people injecting themselves with drugs; $6 \%$ were sexual workers; $46 \%$ were from the general population [2]. In regions with a high prevalence of HIV infection, such as Eastern and Southern Africa, HIV was primarily present in persons from the general population, while in regions with a lower prevalence of HIV it was primarily present amongst persons from key populations and their sexual partners.

The estimation that a significant number of people in the world who are HIV positive are not aware of that fact is a cause for concern, with this percentage ranging from $30 \%$ to $50 \%$ in the European region. In the period between 1984 and the end of 2017, 3,664 HIV positive persons were registered in the Republic of Serbia, of whom 1,901 developed AIDS, and 1,110 died of AIDS. UNAIDS and WHO estimations indicate that, at the end of 2018, in Serbia, 3,000 $(2,200-3,800)$ were living with HIV, of whom between 400 and 1,200 were not aware that they had been infected [3].

All the above stated indicates that, despite numerous new developments in virology and pharmacology, despite intensive efforts in therapy, early diagnostics and prophylaxis, HIV remains one of the greatest 
rada na terapiji, ranoj dijagnostici i profilaksi infekcije, HIV i dalje jedan od najvećih javnozdravstvenih problema u svetu, i u Srbiji. Cilj rada je bio da se analizira kretanje novodijagnostikovanih osoba inficiranih HIV-om, kao i obolelih i umrlih od AIDS-a, među muškarcima i ženama u Srbiji za period 2007 - 2017. godine.

\section{MATERIJAL I METODE}

Podaci o novodijagnostikovanim osobama pozitivnim na HIV (odnosno, inficirani HIV-om u daljem tekstu), obolelima i umrlima od AIDS-a preuzeti su iz Izveštaja o zaraznim bolestima u Republici Srbiji za period od 2007. do 2017. godine, koje godišnje publikuje Institut za javno zdravlje Srbije „Dr Milan Jovanović Batut" i koji su dostupni na sajtu Instituta [4].

Podaci o zaraznim bolestima koje se prenose polnim putem prikupljaju se u okviru epidemiološkog nadzora koji organizuju i sprovode 24 instituta, odnosno zavoda za javno zdravlje, u saradnji sa zdravstvenim ustanovama, u skladu sa zakonom. Prema Pravilniku o prijavljivanju zaraznih bolesti definisana je dinamika i način dostavljanja podataka iz epidemiološkog nadzora [3]. U Institutu za javno zdravlje Srbije "Dr Milan Jovanović Batut" podaci se prikupljaju u vidu zbirnih izveštaja na nedeljnom i mesečnom nivou, osim podataka o novoregistrovanim slučajevima nosilaštva anti-HIV antitela, odnosno oboljevanja i umiranja od AIDS-a, koji se dostavljaju kontinuirano iz zdravstvenih ustanova putem specifične individualne prijave Institutu za javno zdravlje Srbije „Dr Milan Jovanović Batut" (Centralni registar osoba inficiranih HIV-om u Republici Srbiji od 2002. godine i Centralni registar osoba obolelih i umrlih od AIDS-a u Republici Srbiji od 1985. godine). U okviru godišnjih izveštaja 24 instituta/zavoda za javno zdravlje u Srbiji, koji su nadležni na teritoriji 25 okruga, dostavljaju se detaljniji podaci u pogledu pola i uzrasta osoba obolelih i umrlih od polno prenosivih bolesti [4].

Na osnovu dobijenih podataka izračunate su uzrasno-specifične i standardizovane stope novodijagnostikovanih osoba inficiranih HIV-om, kao i uzrasno-specifične i standardizovane stope incidencije i mortaliteta od AIDS-a. Direktnom metodom standardizacije izračunate su standardizovane stope, a za standardnu populaciju korišćena je populacija sveta prema Segiju [5]. Trendovi standardizovanih stopa incidencije i mortaliteta su izračunati korišćenjem joinpoint regresione analize (Joinpoint Regression Program, Version 4.7.0.0. February, 2019; Statistical Methodology and Applications Branch, Surveillance Research Program, National Cancer Institute), prema metodu Kima i saradnika [5]. Joinpoint regresionom analizom određena je prosečna procentualna godišnja promena (engl. Average Annual Percent public health problems in the world, Serbia included. The aim of this paper was to analyze the trend regarding newly diagnosed persons infected with HIV, as well as those who had developed AIDS, and who had died of this disease, amongst men and women in Serbia, in the period between 2007 and 2017.

\section{MATERIALS AND METHODS}

Data on newly diagnosed HIV positive persons (hereinafter: HIV-infected persons), persons who had developed AIDS, and persons who had died of AIDS, were taken from the Reports on Infectious Diseases in the Republic of Serbia for the period between 2007 and 2017, which are annually issued by the Institute of Public Health of Serbia Dr Milan Jovanović Batut, and are available on the Institute's website [4].

Data on infectious sexually transmitted diseases are collected as a part of epidemiological monitoring, which is organized and implemented by 24 different public health institutes, in cooperation with health institutions, and in keeping with the law. The Rulebook on Reporting Infectious Diseases defines the dynamics and method of delivering data collected as part of epidemiological surveillance. [3]. At the Institute of Public Health of Serbia Dr Milan Jovanović Batut data are collected in the form of aggregated reports, on a weekly and monthly basis, with the exception of data on newly registered cases of anti-HIV antibody carriers and cases of patients developing or dying of AIDS, which are continuously reported by health institutions, via special individual report, to the Institute of Public Health of Serbia Dr Milan Jovanović Batut (Central Register of HIV-infected persons in the Republic of Serbia, as of 2002, and the Central Register of Persons Suffering from and Dying of AIDS in the Republic of Serbia, as of 1985). Within the annual reports from the 24 public health institutes in Serbia, which have mandates on the territories of the 25 districts, more detailed data are submitted regarding the sex and age of persons suffering from and dying of sexually transmitted diseases [4].

Based on the data obtained, age-specific and standardized rates of newly diagnosed HIV-infected persons were calculated, as well as age-specific and standardized rates of AIDS incidence and mortality rates of AIDS. Standardized rates were calculated via the direct method of standardization, while Segi's world population was applied for the standard population [5]. The trends of standardized incidence and mortality rates were calculated by means of the joinpoint regression analysis (Joinpoint Regression Program, Version 4.7.0.0. February, 2019; Statistical Methodology and Applications Branch, Surveillance Research Program, National Cancer Institute), applying the method by Kim et al. [5]. The average annual percent change (AAPC) was calculated by means of the joinpoint regression analysis. Years was set as an 
Change - AAPC). Kao nezavisna varijabla postavljene su godine, dok je zavisna varijabla bila odgovarajuća uzrasno-specifična, odnosno standardizovana stopa. Korišćen je Grid Search metod [7]. Pored toga, 95-postotni intervali poverenja računati su za svaku procenu $A A P C-a$, kako bi se utvrdilo da li je $A A P C$ različit od 0 . Korišćen je test uporedivosti da bi se uporedile dve linije regresije. Glavni cilj testa uporedivosti bio je upoređivanje dva seta podataka o trendovima, čije su srednje funkcije predstavljene joinpoint regresijom; odnosno, ispitivanje da li su dve srednje vrednosti regresione funkcije paralelne (test paralelizma) [8].

\section{REZULTATI}

U Srbiji je u periodu 2007 - 2017. godine bilo 1.411 muškaraca i 148 žena inficiranih HIV-om (Tabela 1). Prosečno se godišnje HIV-om inficiralo 127 muškaraca i 13 žena. Najveće uzrasno-specifične stope novodijagnostikovanih osoba inficiranih HIV-om (na

Tabela 1. Broj inficiranih HIV-om, prosečne uzrasno-specifične istandardizovane stope* novodijagnostikovanih osoba inficiranih HIV-om (na 100.000) ijoinpoint regresiona analiza, Srbija, 2007-2017.

\begin{tabular}{|c|c|c|c|c|c|c|}
\hline \multirow[b]{2}{*}{ Uzrast } & \multicolumn{3}{|c|}{ Muškarci / Men } & \multicolumn{3}{|c|}{ Žene / Women } \\
\hline & $\begin{array}{l}\text { Broj novodijagnostikovanih } \\
\text { osoba inficiranih HIV-om za } \\
\text { period } 2007-2017 .\end{array}$ & $\begin{array}{c}\text { Prosečne stope } \\
\text { novodijagnostikovanih osoba } \\
\text { inficiranih HIV-om }\end{array}$ & $\begin{array}{c}\text { AAPC } \\
(95 \% \text { IP) }\end{array}$ & $\begin{array}{l}\text { Broj novodijagnostikovanih } \\
\text { osoba inficiranih } \\
\text { HIV-om za period 2007-2017. }\end{array}$ & $\begin{array}{c}\text { Prosečne stope } \\
\text { novodijagnostikovanih osoba } \\
\text { inficiranih HIV-om }\end{array}$ & $\begin{array}{c}\text { AAPC } \\
(95 \% \text { IP) }\end{array}$ \\
\hline Age & $\begin{array}{l}\text { Number of newly diagnosed } \\
\text { HIV-infected persons for the } \\
\text { period 2007-2017 }\end{array}$ & $\begin{array}{l}\text { Average rates of newly } \\
\text { diagnosed } \\
\text { HIV-infected persons }\end{array}$ & $\begin{array}{c}A A P C \\
(95 \% \text { Cl) }\end{array}$ & $\begin{array}{l}\text { Number of newly diagnosed } \\
\text { HIV-infected persons for the } \\
\text { period 2007-2017 }\end{array}$ & $\begin{array}{l}\text { Average rates of newly } \\
\text { diagnosed } \\
\text { HIV-infected persons }\end{array}$ & $\begin{array}{c}A A P C \\
(95 \% \text { CI) }\end{array}$ \\
\hline $0-14$ & 7 & 0.1 & $\begin{array}{c}-8.3 \\
(-37.1,33.6)\end{array}$ & 4 & 0.1 & - \\
\hline $15-19$ & 18 & 0.8 & $\begin{array}{c}23.7 \\
(-16.4,83.1)\end{array}$ & 0 & 0.1 & - \\
\hline $20-24$ & 169 & 6.7 & $\begin{array}{c}7.6 \\
(-0.5,16.4)\end{array}$ & 15 & 1.4 & $\begin{array}{c}22.2 \\
(-21.2,89.4)\end{array}$ \\
\hline $25-29$ & 320 & 11.8 & $\begin{array}{c}5.0 \\
(-1.4,11.8)\end{array}$ & 21 & 2.1 & $\begin{array}{c}2.8 \\
(-34.4,44.1)\end{array}$ \\
\hline $30-39$ & 478 & 8.6 & $\begin{array}{c}8.7 \wedge \\
(5.5,11.9)\end{array}$ & 44 & 2.0 & $\begin{array}{c}9.7 \\
(-15.1,41.8)\end{array}$ \\
\hline $40-49$ & 246 & 4.6 & $\begin{array}{c}9.6 \wedge \\
(3.0,16.6)\end{array}$ & 34 & 1.2 & $\begin{array}{c}18.3 \\
(-18.6,71.9)\end{array}$ \\
\hline $50-59$ & 122 & 2.1 & $\begin{array}{c}15.4 \wedge \\
(1.8,30.9)\end{array}$ & 19 & 0.5 & $\begin{array}{c}26.8 \\
(-14.2,87.2)\end{array}$ \\
\hline $60+$ & 51 & 0.6 & $\begin{array}{c}4.3 \\
(-6.0,15.6)\end{array}$ & 11 & 0.2 & $\begin{array}{c}4.3 \\
(-6.0,15.6)\end{array}$ \\
\hline $\begin{array}{l}\text { Ukupno } \\
\text { / Total }\end{array}$ & 1.411 & $3.6\left(3.4^{*}\right)$ & $\begin{array}{c}7.0 \wedge \\
(3.9,10.3)^{*}\end{array}$ & 148 & $0.8\left(0.8^{*}\right)$ & $\begin{array}{c}22.1^{\wedge} \\
(2.4,45.5)^{*}\end{array}$ \\
\hline
\end{tabular}

AAPC - prosečna procentualna godišnja promena za period 2007-2017.;

$\wedge$ AAPC je zanačajno različito od 0 za alfa 0,05 ;

95\% IP - 95\% interval poverenja;

* standardizovana stopa prema populaciji sveta;

- nemoguće izračunati trend zbog malih vrednosti stopa independent variable, while the appropriate age-specific, i.e. standardized rate was set as a dependent variable. The Grid Search method was applied [7]. Additionally, 95-percent confidence intervals were calculated for each AAPC assessment, in order to determine whether the AAPC is different from 0 . The comparability test was applied in order to compare two lines of regression. The main goal of the comparability test was to compare two sets of data on trends, whose mean functions were represented via joinpoint regression, i.e. to test whether the two mean values of the regression function were parallel (parallelism test) [8].

\section{RESULTS}

In Serbia, in the period between 2007 and 2017 there were 1,411 men and 148 women infected with HIV (Table 1). On average, 127 men and 13 women were infected with HIV, annually. The highest age-specific rates of newly diagnosed HIV-infected persons (per 100,000)

Table 1. Number of HIV-infected persons, average age-specific and standardized rates* of newly diagnosed HIV-infected persons (per 100,000) and joinpoint regression analysis for Serbia, 2007-2017.
AAPC - average annual percent change, for the period 2007-2017;

$\wedge$ AAPC is significantly different from 0 by alpha 0.05 ;

95\% Cl - 95\% confidence interval;

* standardized rate according to the world population;

- impossible to calculate the trend due to small rate values 
100.000) bile su u uzrasnim grupama 25 - 29 godina (muškarci 11,8 i žene 2,1) i 30 - 39 godina (muškarci 8,6 i žene 2,0). Prosečne standardizovane stope novodijagnostikovanih osoba inficiranih HIV-om bile su 4,3 puta veće za muškarce $(3,4 / 100.000)$ nego za žene $(0,8 / 100.000)$. Značajan porast stopa novodijagnostikovanih osoba inficiranih HIV-om, u posmatranom periodu 2007 - 2017, zabeležen je kod muškaraca za uzraste: 30 - 39 godina od 8,7\% godišnje, 40 - 49 godina od $9,6 \%$ godišnje, i 50 - 59 godina od $15,4 \%$ godišnje, dok kod žena nije uočen značajan porast po uzrasnim grupama. Kada se posmatraju svi uzrasti zajedno, uočava se značajan porast standardizovane stope novodijagnostikovanih osoba inficiranih HIV-om, kod muškaraca od $7 \%$ godišnje, a kod žena od $22,1 \%$ godišnje.

U periodu od 2007. do 2017. godine u Srbiji je 458 muškaraca i 77 žena obolelo od AIDS-a (Tabela 2). Prosečno su godišnje od AIDS-a obolevala 42 muškarca i 7 žena. Najveće uzrasno-specifične stope incidencije za AIDS (na 100.000) bile su u uzrasnim grupama 40 - 49 godina (2,7 muškarci i 0,5 žene) i 30 - 39 godina (2,6 muškarci i 0,4 žene). Prosečne standardizovane stope incidencije za AIDS bile su 4,5 puta veće za

Tabela 2. Broj obolelih od AIDS-a, prosečne uzrasno-specifične istandardizovane stope $^{*}$ incidencije (na 100.000) i joinpoint regresiona analiza, Srbija, 2007 2017.

\begin{tabular}{|c|c|c|c|c|c|c|}
\hline \multirow[b]{2}{*}{ Uzrast } & \multicolumn{3}{|c|}{ Muškarci / Men } & \multicolumn{3}{|c|}{ Žene / Women } \\
\hline & $\begin{array}{c}\text { Broj osoba obolelih } \\
\text { od AIDS-a za period } 2007-2017 .\end{array}$ & $\begin{array}{c}\text { Prosečne stope } \\
\text { incidencije AIDS-a }\end{array}$ & $\begin{array}{c}A A P C \\
(95 \% \mathrm{IP})\end{array}$ & $\begin{array}{l}\text { Broj osoba obolelih } \\
\text { od AIDS-a za period 2007-2017. }\end{array}$ & $\begin{array}{c}\text { Prosečne stope } \\
\text { incidencije AIDS-a }\end{array}$ & $\begin{array}{c}A A P C \\
(95 \% \mathrm{IP})\end{array}$ \\
\hline Age & $\begin{array}{l}\text { Number persons suffering from } \\
\text { AIDS for the period } 2007-2017\end{array}$ & $\begin{array}{l}\text { Average rates of AIDS } \\
\text { incidence }\end{array}$ & $\begin{array}{l}A A P C \\
(95 \%(l)\end{array}$ & $\begin{array}{l}\text { Number persons suffering from AIDS } \\
\text { for the period } 2007-2017\end{array}$ & $\begin{array}{l}\text { Average rates of AIDS } \\
\text { incidence }\end{array}$ & $\begin{array}{c}A A P C \\
(95 \%(l)\end{array}$ \\
\hline $0-14$ & 3 & 0.0 & - & 2 & 0.0 & - \\
\hline $15-19$ & 0 & 0.0 & - & 0 & 0.0 & - \\
\hline $20-24$ & 15 & 0.6 & $\begin{array}{c}2.1 \\
(-31.3,51.8)\end{array}$ & 1 & 0.0 & - \\
\hline $25-29$ & 54 & 2.0 & $\begin{array}{c}4.6 \\
(-8.8,19.9)\end{array}$ & 5 & 0.2 & - \\
\hline $30-39$ & 143 & 2.6 & $\begin{array}{c}7.5^{\wedge} \\
(1.1,14.2)\end{array}$ & 24 & 0.4 & $\begin{array}{c}-27.8 \wedge \\
(-45.5,-4.3)\end{array}$ \\
\hline $40-49$ & 141 & 2.7 & $\begin{array}{c}7.2 \wedge \\
(0.9,13.9)\end{array}$ & 27 & 0.5 & $\begin{array}{c}-22.6 \\
(-44.3,7.6)\end{array}$ \\
\hline $50-59$ & 71 & 1.3 & $\begin{array}{c}19.8 \wedge \\
(6.2,35.1)\end{array}$ & 15 & 0.3 & $\begin{array}{c}16.9 \\
(-18.3,67.2)\end{array}$ \\
\hline $60+$ & 31 & 0.4 & $\begin{array}{c}10.2 \\
(-22.2,56.3)\end{array}$ & 3 & 0.1 & $\begin{array}{c}-14.3 \wedge \\
(-25.9,-0.8)\end{array}$ \\
\hline $\begin{array}{l}\text { Ukupno } \\
\text { / Total }\end{array}$ & 458 & $1.2\left(0.9^{*}\right)$ & $\begin{array}{c}4.9 \wedge \\
(0.6,9.4)\end{array}$ & 77 & $0.2\left(0.2^{*}\right)$ & $\begin{array}{c}-12.2^{\wedge} \\
(-20.7,-2.9)\end{array}$ \\
\hline
\end{tabular}

$A A P C$ - prosečna procentualna godišnja promena za period 2007-2017.;

$\wedge$ AAPC je značajno različito od 0 za alfa 0,05;

95\% IP - 95\% interval poverenja;

* standardizovana stopa prema populaciji sveta;

- nemoguće izračunati trend zbog malih vrednosti stopa were in the age group of 25 - 29 years (men - 11.8; women -2.1 ) and the age group of $30-39$ years (men - 8.6; women -2.0 ). The average standardized rates of newly diagnosed HIV-infected persons were 4.3 times higher for men $(3.4 / 100,000)$ than for women $(0.8 / 100,000)$. A significant rise in rates of newly diagnosed HIV-infected persons, during the observation period 2007 - 2017, was registered in men, for the age groups: 30 - 39 years, amounting to $8.7 \%$ per year; 40 - 49 years, amounting to $9.6 \%$ per year; and 50 - 59 years, amounting to $15.4 \%$ per year; while in women no significant rise was registered in each of the different age groups. When all age groups are observed together, a significant rise in the standardized rate of newly diagnosed HIV-infected persons is apparent; in men, amounting to $7 \%$ per year, and in women, amounting to $22.1 \%$, per year.

In Serbia, in the period between 2007 and 2017, 458 men and 77 women developed AIDS (Table 2). On average, 42 men and 7 women developed AIDS each year. The highest age-specific incidence rates for AIDS (per 100,000) were in the age groups: 40 - 49 years, $(2.7$ for men and 0.5 for women) and $30-39$ years ( 2.6 for men and 0.4 for women). The average standardized incidence rates for AIDS were 4.5 times higher for men $(0.9 / 100,000)$ than for

Table 2. Number of persons suffering from AIDS, average age-specific and standardized rates* of incidence (per 100,000) and joinpoint regression analysis for Serbia, 2007-2017.

AAPC - average annual percent change, for the period 2007-2017;

$\wedge$ AAPC is significantly different from 0 by alpha 0.05 ;

$95 \% \mathrm{Cl}-95 \%$ confidence interval

* standardized rate according to the world population;

- impossible to calculate the trend due to small rate values 
muškarce $(0,9 / 100.000)$ nego za žene $(0,2 / 100.000)$. Značajan porast stopa incidencije AIDS-a kod muškaraca u posmatranom periodu zabeležen je za uzraste 30 - 39 godina od $7,5 \%$ godišnje, 40 - 49 godina od $7,2 \%$ godišnje i 50 - 59 godina od $19,8 \%$ godišnje, kao i za sve uzraste $4,9 \%$ godišnje. Međutim, kada se posmatraju uzrasno-specifične stope kod žena, zapaža se značajan godišnji pad od $-27,8 \%$ za uzrast $30-39$ godina, $-14,3 \%$ za uzrast preko 60 godina, i za sve uzraste $-12,2 \%$.

U Srbiji je u periodu od 2007. do 2017. godine od AIDS-a umro 171 muškarac i 31 žena (Tabela 3). Prosečno je godišnje od AIDS-a umiralo 16 muškarca i 3 žene. Najveće stope mortaliteta (na 100.000) bile su u uzrasnoj grupi 40 - 49 godina kod muškaraca $(1,1)$ i kod žena za uzraste 30 - 39 i $40-49(0,2)$. Prosečne standardizovane stope mortaliteta od AIDS-a bile su četiri puta veće za muškarce $(0,4 / 100.000)$ nego za žene $(0,1 / 100.000)$. Kada se posmatraju trendovi kretanja uzrasno-specifičnih i standardizovanih stopa mortaliteta, kod muškaraca za poslednjih jedanaest godina nema značajnih promena, dok je kod žena prisutan značajan

Tabela 3. Broj umrlih od AIDS-a, prosečne uzrasno-specifične i standardizovane stope mortaliteta* (na 100.000) ijoinpoint regresiona analiza, Srbija, 2007-2017. women (0.2/100,000). A significant rise in AIDS incidence rates in men, during the observation period, was registered for the age groups: 30 - 39 years, amounting to $7.5 \%$ per year; 40 - 49 years, amounting to $7.2 \%$ per year; 50 59 years, amounting to $19.8 \%$ per year; as well as $4.9 \%$ per year for all ages combined. However, when age-specific rates are observed in women, a significant yearly decline is apparent, amounting to: $-27.8 \%$, for the age group of 30 - 39 years; $-14.3 \%$, for the age group of persons over 60 years; as well as $-12.2 \%$, for all ages combined.

In Serbia, in the period between 2007 and 2017, 171 men and 31 women died of AIDS (Table 3). On average, 16 men and 3 women died of AIDS each year. The highest mortality rates (per 1000,000) were in the age group of 40 - 49 years, for men (1.1), while in women they were the highest in the age groups of $30-39$ years and $40-49$ years (0.2). Average standardized AIDS-related mortality rates were four times higher for men $(0.4 / 100,000)$ than for women $(0.1 / 100,000)$. When the trends of age-specific and standardized mortality rates are observed, in men, there have been no significant changes in the past 11 years, while in women, a significant annual decline is

Table 3. Number of AIDS-related deaths, average age-specific and standardized mortality rates* (per 100,000) and joinpoint regression analysis for Serbia, 2007-2017.

\begin{tabular}{|c|c|c|c|c|c|c|}
\hline \multirow[b]{2}{*}{ Uzrast } & \multicolumn{3}{|c|}{ Muškarci / Men } & \multicolumn{3}{|c|}{ Žene / Women } \\
\hline & $\begin{array}{l}\text { Broj osoba umrlih od AIDS-a za } \\
\text { period 2007-2017. }\end{array}$ & $\begin{array}{l}\text { Prosečne stope } \\
\text { mortaliteta od AIDS-a }\end{array}$ & $\begin{array}{c}\text { AAPC } \\
(95 \% \mathbb{P})\end{array}$ & $\begin{array}{l}\text { Broj osoba umrlih od AIDS-a za } \\
\text { period 2007-2017. }\end{array}$ & $\begin{array}{l}\text { Prosečne stope } \\
\text { mortaliteta od AIDS-a }\end{array}$ & $\begin{array}{c}\text { AAPC } \\
(95 \% \mathrm{IP})\end{array}$ \\
\hline Age & $\begin{array}{l}\text { Number of AIDS-related deaths } \\
\text { for the period 2007-2017 }\end{array}$ & $\begin{array}{l}\text { Average AIDS-related } \\
\text { mortality rates }\end{array}$ & $\begin{array}{c}A A P C \\
(95 \% C l)\end{array}$ & $\begin{array}{c}\text { Number of AIDS-related deaths } \\
\text { for the period 2007 - } 2017\end{array}$ & $\begin{array}{c}\text { Average AIDS-related } \\
\text { mortality rates }\end{array}$ & $\begin{array}{c}A A P C \\
(95 \%(I)\end{array}$ \\
\hline $0-14$ & 2 & 0.0 & - & 0 & 0.0 & - \\
\hline $15-19$ & 0 & 0.0 & - & 0 & 0.0 & - \\
\hline $20-24$ & 5 & 0.2 & - & 1 & 0.0 & - \\
\hline $25-29$ & 16 & 0.6 & $\begin{array}{c}-2.3 \\
(-38.6,55.4)\end{array}$ & 1 & 0.0 & - \\
\hline $30-39$ & 40 & 0.7 & $\begin{array}{c}-0.2 \\
(-10.4,11.2)\end{array}$ & 11 & 0.2 & - \\
\hline $40-49$ & 55 & 1.1 & $\begin{array}{c}-13.1 \\
(-36.7,19.1)\end{array}$ & 11 & 0.2 & $\begin{array}{c}-25.8 \wedge \\
(-43.5,-2.6)\end{array}$ \\
\hline $50-59$ & 35 & 0.6 & $\begin{array}{c}2.9 \\
(-10.5,18.2)\end{array}$ & 6 & 0.1 & - \\
\hline $60+$ & 18 & 0.2 & $\begin{array}{c}-13.5 \\
(-34.8,15.0)\end{array}$ & 1 & 0.01 & - \\
\hline $\begin{array}{l}\text { Ukupno } \\
\text { / Total }\end{array}$ & 171 & $0.4\left(0.4^{*}\right)$ & $\begin{array}{c}-1.6 \\
(-15.9,15.0)^{*}\end{array}$ & 31 & $0.1\left(0.1^{*}\right)$ & $\begin{array}{c}-13.9 \wedge \\
(-25.3,-0.7)^{*}\end{array}$ \\
\hline
\end{tabular}

AAPC - prosečna procentualna godišnja promena za period 2007-2017; $\wedge$ AAPC je značajno različito od 0 za alfa 0,05 ; 95\% IP - 95\% interval poverenja;

* standardizovana stopa prema populaciji sveta;

- nemoguće izračunati trend zbog malih vrednosti stopa
AAPC - average annual percent change, for the period 2007-2017;

$\triangle$ AAPC is significantly different from 0 by alpha 0.05 ; $95 \% \mathrm{Cl}-95 \%$ confidence interval;

* standardized rate according to the world population; - impossible to calculate the trend due to small rate valuess 
a) Kretanje standardizovanih stopa novodijagnostikovanih osoba inficiranih HIV-om po polu / Trend of standardized rates of newly diagnosed HIVinfected persons by gender

Muškarci: 1 Joinpoint versus Zene: 1 Joinpoint Men: 1 Joinpoint versus Women: 1 Joinpoint

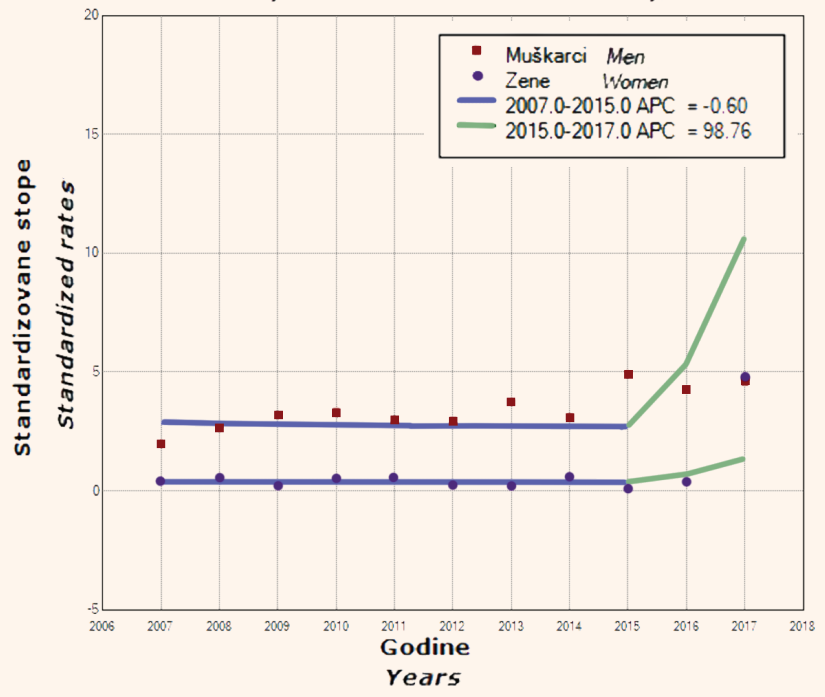

Indicates that the Annual Percent Change (APC) is significanty different from zero at the alpha $=0,05$ level. Final Selected Model: Muškarci/Men - 1 Joinpoint, Žene/Women - 1 Joinpoint. Failed to reject Parallelism.

c) Kretanje standardizovanih stopa mortaliteta od AIDS-a po polu / Trend of standardized AIDS-related mortality rates by gender

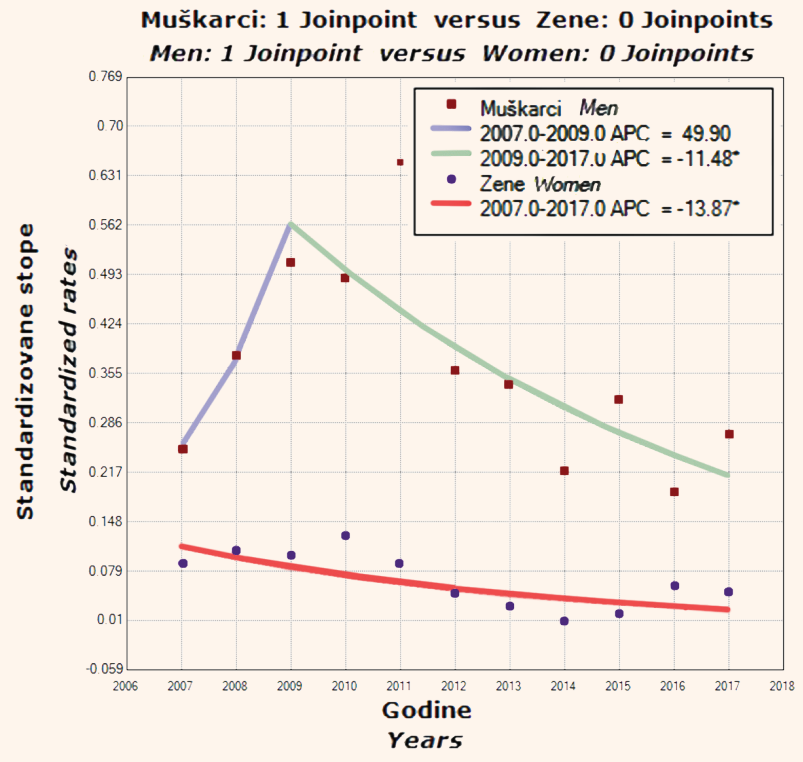

Indicates that the Annual Percent Change (APC) is significanty different from zero at the alpha $=0,05$ level. Final Selected Model: Muškarci/Men - 1 Joinpoint, Žene/Women - 0 Joinpoints. Rejected Parallelism.

godišnji pad od $-25,8 \%$ za uzrast 40 - 49 godina, kao i za sve uzraste od $-13,9 \%$.

Prema testu uporedivosti trendova stopa novodijagnostikovanih osoba inficiranih HIV-om, između polova, kao i stopa incidencije AIDS-a, između muškaraca i žena, trendovi su bili paralelni (konačni izabrani model nije uspeo da odbaci paralelizam, $p=0,221$ za HIV i $p=0,093$ za AIDS) (Grafikon 1, a i b). Međutim, prema testu uporedivosti, trendovi stopa mortaliteta od AIDS-a kod muškaraca i žena nisu bili paralelni (konačni izabrani model odbacio je paralelizam, $p=0,037$ ) (Grafikon 1, c). b) Kretanje standardizovanih stopa incidencije AIDS-a po polu/ Trend of standardized AIDS incidence rates by gende

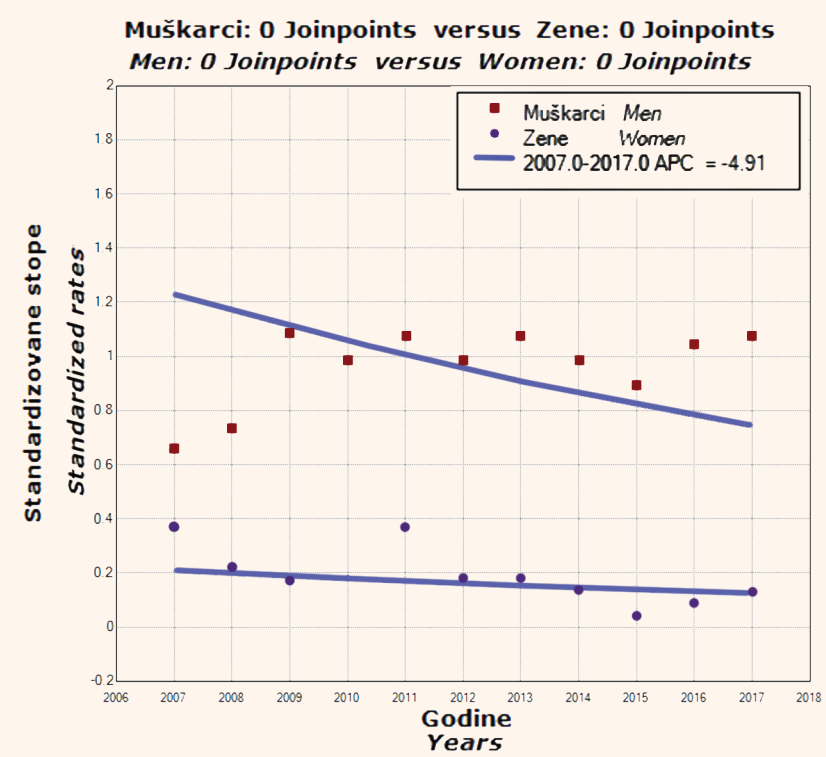

Indicates that the Annual Percent Change (APC) is significanty different from zero at the alpha $=0,05$ level. Final Selected Model: Muškarci/Men - 0 Joinpoints, Žene/Women - 0 Joinpoints. Failed to reject Parallelism.

Grafikon 1. Joinpoint regresiona analiza kretanja standardizovanih stopa novodijagnostikovanih osoba inficiranih HIV-om (a), stopa incidencije obolelih od AIDS-a (b) i stopa mortaliteta od AIDS-a (c) po polu

Figure 1. Joinpoint regression analysis of the trends of standardized rates of newly diagnosed HIV-infected persons (a), incidence rates of persons suffering from AIDS (b), and AIDS-related mortality rates (c), by gender

visible, amounting to $-25.8 \%$, for the age group of 40 49 years, as well as $-13.9 \%$, for all ages combined.

According to the comparability test of rate trends of newly diagnosed HIV-infected persons, between the two sexes, as well as the AIDS incidence rates, in men and women, the trends were parallel (the final selected model did not succeed in rejecting parallelism, $p=0.221$ for HIV; $p=0.093$ for AIDS) (Figure 1, a and b). However, according to the comparability test, AIDS-related mortality rate trends, in men and women, were not parallel (the final selected model succeeded in 
Stope mortaliteta od AIDS-a kod žena značajno su opadale za 13,9\% godišnje, dok kod muškaraca nije bilo značajne promene u celokupnom posmatranom periodu.

Prema načinu transmisije, tokom perioda od 2007. do 2017. godine, kod muškaraca kojima je novodijagnostikovana HIV infekcija, nezaštićeni analni seksualni kontakt među muškarcima je bio najčešći način transmisije $(69,0 \%)$, (Grafikon 2), zatim heteroseksualni odnos $(13,9 \%)$, korišćenje droge injektiranjem rejecting parallelism, $p=0.037$ ) (Figure $1, \mathrm{c}$ ). AIDS-related mortality rates in women decreased significantly by $13.9 \%$ per year, while in men there was no significant change in the whole observation period.

As to the modes of transmission, during the period between 2007 and 2017, in men newly diagnosed with HIV infection, unprotected anal sexual intercourse amongst men was the most common way of transmission (69.0\%) (Figure 2); followed by heterosexual
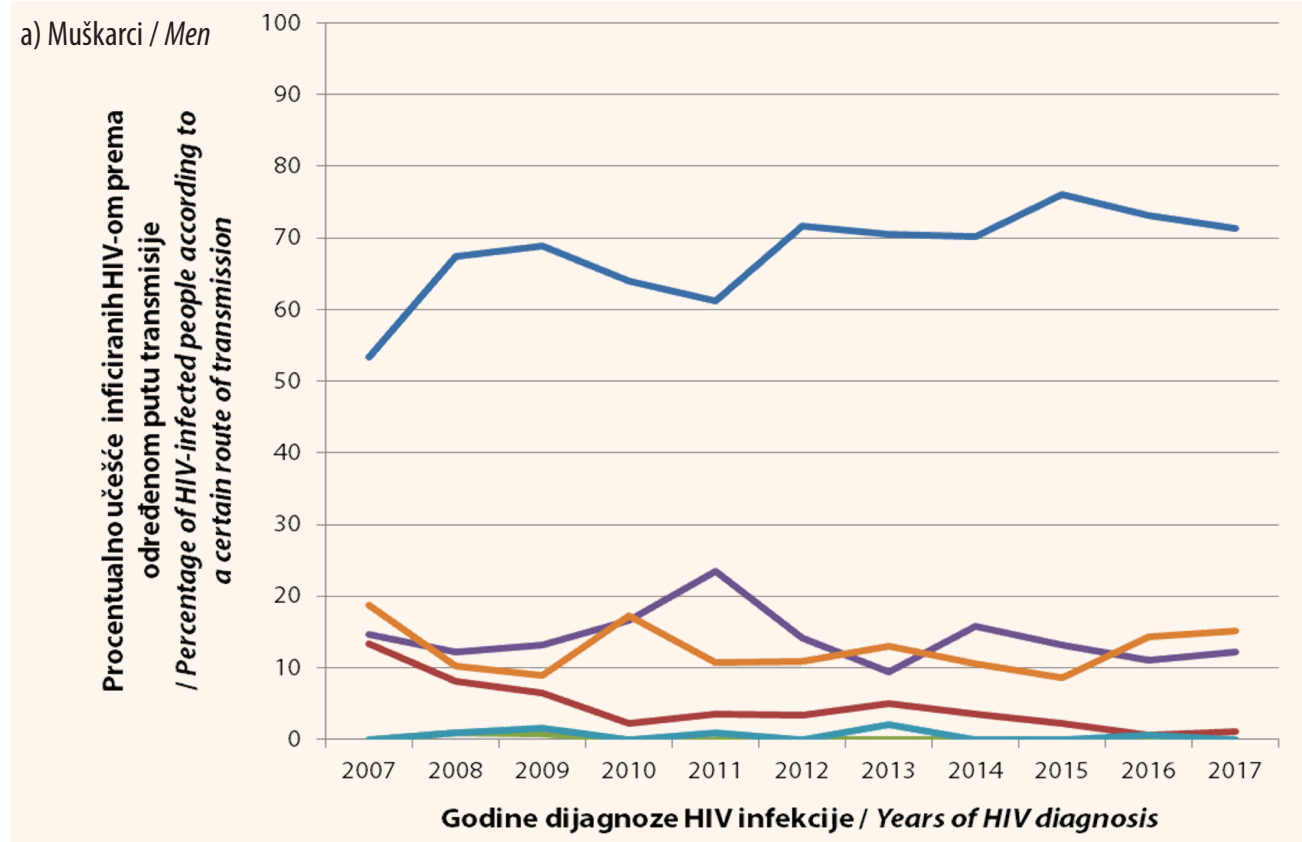

b) Žene / Women

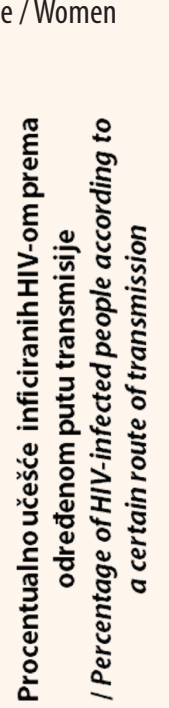$$
\begin{aligned}
& 100 \\
& 90 \\
& 80 \\
& 70 \\
& 60 \\
& 50 \\
& 40 \\
& 30 \\
& 20 \\
& 10
\end{aligned}
$$

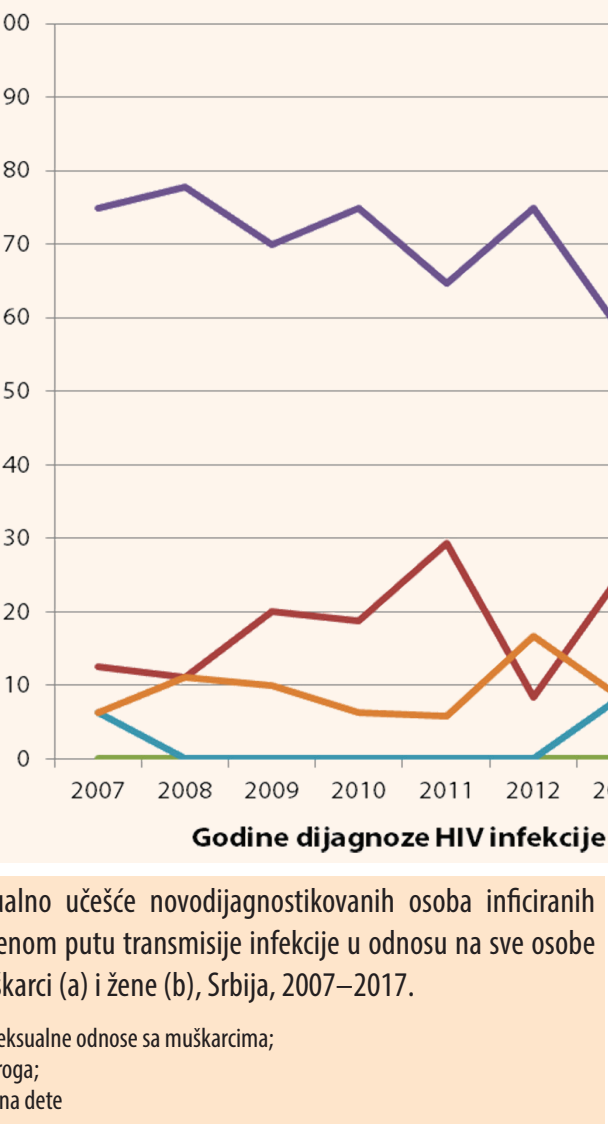

Grafikon 2. Procentualno učešće novodijagnostikovanih osoba inficiranih HIV-om prema prijavljenom putu transmisije infekcije u odnosu na sve osobe inficirane HIV-om, muškarci (a) i žene (b), Srbija, 2007-2017.

MSM - muškarci koji imaju seksualne odnose sa muškarcima;

IKD - injektirajući korisnici droga;

MTCT - transmisija sa majke na dete
MTCT - Mother-to-child transmission

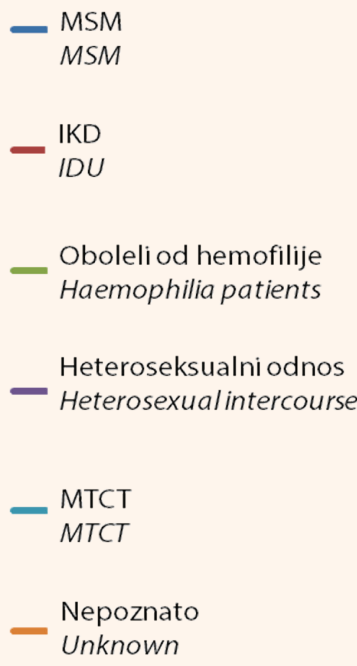

$-\stackrel{I K D}{I D U}$

Primaoci transfuzije
Blood transfusion
recipients

_ Heteroseksualniodnos Heterosexual intercourse

MTCT
- MTCT

Nepoznato

- Unknown
Figure 2. Percentage of newly diagnosed persons infected with HIV according to the reported route of transmission of infection in relation to all HIV-infected persons, men (a) and women (b), Serbia, 2007-2017.

MSM - Men who have sex with men;

IDU - Intravenous drug users; 
$(3,9 \%)$, transmisija sa majke na dete $(0,6 \%)$, primaoci faktora koagulacije i preparata krvi usled deficita faktora koagulacije $(0,1 \%)$, dok je za $12,5 \%$ muškaraca način transmisije bio nepoznat. $U$ posmatranom periodu, u MSM populaciji registruje se rastući trend novodijagnostikovanih muškaraca inficiranih HIV-om, dok se kod injektirajućih korisnika droga zapaža pad. Kod žena je, u posmatranom periodu, dominantan put prenosa bio nezaštićen heteroseksualni odnos $(75,7 \%)$, dok je injektirajućih korisnica droga (IKD) bilo $14,2 \%$, transmisija sa majke na dete je bilo $2,7 \%$, a primaoca transfuzije $0,7 \%$. Za $6,1 \%$ žena put prenosa ostao je nepoznat.

\section{DISKUSIJA}

U Srbiji su, u periodu od 2007. do 2017. godine, prosečne standardizovane stope (na 100.000) inficiranih HIV-om iznosile 3,4 za muškarce i 0,8 za žene, odnosno bile su 4,3 puta veće kod muškaraca nego žena. Kod muškaraca je, u posmatranom periodu, došlo do prosečnog godišnjeg porasta stope inficiranih HIV-om za $7 \%$, a kod žena za 22,1\%. Najveći prosečan godišnji porast $(+15,4 \%)$ bio je kod muškaraca u uzrastu 50 - 59 godina, a kod žena u svim uzrasnim grupama nije postojala značajna promena.

Istraživanje sprovedeno u Rumuniji imalo je za cilj $\mathrm{da}$, na osnovu podataka o dinamici oboljevanja od AIDS-a od 2004. do 2016. godine, prognozira kretanje infekcije u Rumuniji od 2017. do 2027. godine. Utvrđeno je da postoji značajan porast od $71 \%$ u broju inficiranih HIV-om od 2004. do 2016. godine, kao i da se broj obolelih od AIDS-a povećao za $60,3 \%$. Međutim, u Rumuniji, uprkos dostupnosti lekova, lečenju i nezi osoba obolelih od AIDS-a, dolazi do neznatnog smanjenja broja umrlih od AIDS-a. Najveći broj inficiranih HIV-om je bio u uzrastu od 26 do 30 godina, što se poklapa sa epidemiološkom situacijom u Srbiji [9]. Interesantno je da su u Španiji najviše stope novodijagnostikovanih osoba inficiranih HIV-om bile kod osoba mlađih od 20 godina, mada je njihov apsolutni broj bio mali, a zatim u uzrastu 35 - 39 godina. Joinpoint analiza pokazala je porast stopa novodijagnostikovanih osoba inficiranih HIV-om u periodu 2000 - 2009, ali stratifikacija po putevima prenošenja pokazala je da je rastući trend prisutan samo među MSM populacijom [10]. Prema rezultatima druge studije iz Španije, koja je pratila seroprevalenciju HIV infekcije i infekcije uzrokovane virusom hepatitisa $C$ (engl. hepatitis ( virus - HCV) u periodu 2008 - 2012. godine, HIV infekcija je bila češća kod muškaraca, stope HIV i HCV infekcije su bile najveće kod osoba rođenih između 1955 - 1970. godine, a vrhunci ovih infekcija su se poklapali. Seroprevalencija HIV infekcije je rasla intercourse (13.9\%), injection drug abuse (3.9\%), transmission from mother to child $(0.6 \%)$, and receiving coagulation factors and other blood products due to coagulation factor deficit $(0.1 \%)$; while for $12.5 \%$ of men, the mode of transmission remained unknown. During the observation period, within the MSM population, a rising trend in the number of newly diagnosed HIV-infected men was apparent; while in the population of injection drug users, there was a falling trend. During the observation period, in women, the dominant pathway of transmission was unprotected heterosexual intercourse $(75.7 \%)$; while there was $14.2 \%$ of female injection drug users (IDUs); mother to child transmission was present in $2.7 \%$ of the cases; and blood transfusion was the pathway of transmission in $0.7 \%$ of cases. For $6.1 \%$ of women the pathway of transmission was unknown.

\section{DISCUSSION}

In Serbia, in the period between 2007 and 2017, the average standardized rates (per 100,000) of HIV-infected persons were 3.4 , for men, and 0.8 , for women, i.e. they were 4.3 times higher in men than in women. In men, in the observation period, there was an average annual increase in the rate of HIV-infected persons of 7\%, and in women this increase was $22.1 \%$. The greatest average yearly increase $(+15.4 \%)$ was in men aged 50 - 59 years, and in women, there was no significant change in any of the age groups.

Research in Romania was carried out with the aim of predicting, on the basis of data on the dynamics of AIDS between 2004 and 2016, the infection trends in Romania from 2017 to 2027. It was established that there was a significant rise, amounting to $71 \%$, in the number of HIV-infected persons between 2004 and 2016, as well as that the number of AIDS patients increased by $60.3 \%$. Also, despite the availability of medication, treatment and care for AIDS patients in Romania, only a negligible decrease in the number of people dying from AIDS occurred. The largest number of HIV infected persons was in the age group of 26-30 years, which coincides with the epidemiological situation in Serbia [9]. It is interesting that in Spain, the highest rates of newly diagnosed HIV-persons were in persons under the age of 20 years, although their absolute number was small, while the next age group with the highest rates was the one from 35 to 39 years. Joinpoint analysis showed an increase in the rate of newly diagnosed HIV-infected persons in the period between 2000 and 2009, but stratification by modes of transmission showed that a rising trend was present only in the MSM population [10]. According to the results of another study carried out in Spain, which followed the seroprevalence of the HIV infection and infection caused by the hepatitis $C$ virus (HCV), in the period $2008-2012$, HIV infection was more frequent in men, HIV and HCV infection rates were the highest in persons born between 1955 and 1970, and 
sa godinom rođenja, za osobe rođene pre 1965. godine $(53,4 \%$ godišnje), nakon čega se smanjivala za $27,1 \%$ godišnje. Kako HIV i HCV imaju iste puteve prenošenja, smatra se da se porast može objasniti epidemijom injektirajućeg korišćenja droga osamdesetih godina dvadesetog veka, dok je poslednjih godina glavni put prenosa seksualni kontakt (više od $90 \%$ novoinficiranih). Posledično, prevalencija HIV infekcije je u porastu kod mladih [12].

U studiji Lija i saradnika ispitivana je epidemiološka situacija inficiranja HIV-om i oboljevanjem i umiranjem od AIDS-a, u Kini, u periodu od 2004. do 2011. godine [12]. Utvrđen je kontinuirani porast u stopi novodijagnostikovanih osoba inficiranih HIV-om. Mortalitet je efikasno kontrolisan zahvaljujući određenim merama koje su prevashodno usmerene na terapiju. Omogućeno je besplatno testiranje, besplatna terapija za ekonomski ugrožene grupe, savetovanje i besplatna antiretrovirusna terapija za trudnice koje su inficirane HIV-om. Ova studija je pratila stope u različitim regionima Kine. lako je stopa mortaliteta na nivou zemlje pod kontrolom, u određenim regionima kao što su Gansu i Ningsja stopa mortaliteta je bila u porastu. To se pripisuje višestrukim faktorima kao što su loša ekonomska situacija i lošija dostupnost zdravstvene zaštite u tim regionima, slabijem prihvatanju testiranja, velikom broj obolelih koji ne otkrivaju svoj status i prisustvu brojnih oportunističkih infekcija.

Broj ljudi sa novodijagnostikovanom HIV infekcijom u evropskoj regiji SZO-a povećan je za 22\% u poslednjoj deceniji. Stopa novodijagnostikovanih HIV infekcija povećala se za $14 \%$ u poslednjih 10 godina, sa 14,2 u 2009. godini na 16,2 u 2018. godini. Porast je uglavnom posledica rasta broja osoba inficiranih HIV-om u istočnoj Evropi. Upoređujući broj novih dijagnoza sa procenjenim brojem novih HIV infekcija tokom poslednje decenije, primećeno je da se više ljudi inficiralo HIV-om nego što je to dijagnostikovano, što ukazuje da broj ljudi koji živi sa nedijagnostikovanom HIV infekcijom raste u regiji [13].

U Srbiji, u posmatranom jedanaestogodišnjem periodu, kod muškaraca je došlo do značajnog porasta incidencije AIDS-a od 4,9\% godišnje, dok je kod žena zabeležen značajan pad od $12,2 \%$ godišnje. Studija iz 2017. godine koja je pratila kretanje AIDS-a u Italiji od 1999. do 2014. godine mogla bi da pruži objašnjenja za porast obolevanja muškaraca. Uočeno je da muškarci češće ne znaju da su inficirani, te kasnije počinju sa lečenjem. U studiji je dato nekoliko potencijalnih objašnjenja. Prvo, ženama se češće nudi testiranje, kao što je to u trudnoći. Drugo, moguće je češće korišćenje zdravstvene zaštite od strane žena u odnosu na muškarce [14]. Tome u prilog idu i podaci the peaks of these infections overlapped. The seroprevalence of the HIV infection increased with the year of birth for persons born before 1965 (53.4\% per year), after which it decreased by $27.1 \%$ per year. As HIV and HCV have the same pathways of transmission, it is believed that the rise can be explained by the epidemic of injection drug abuse during the eighties of the $20^{\text {th }}$ century, while in recent years, the main pathway of transmission has been sexual contact (more than $90 \%$ of newly HIV-infected persons). Consequently, the prevalence of HIV infection is on the rise in the younger population [12].

In a study by Li et al., the epidemiological situation regarding HIV infection and the development of AIDS, as well as AIDS-related mortality was analyzed in China, in the period between 2004 and 2011 [12]. A continuous rise in the rate of newly diagnosed HIV-infected persons was determined. Mortality was efficiently controlled due to certain measures which were primarily directed towards therapy. Free testing was made available, as well as free therapy for economically vulnerable groups. Counselling and free antiretroviral therapy was provided for pregnant women infected with HIV. This study monitored rates in different regions of China. While the mortality rate at the level of the whole country is under control, in certain regions, such as Gansu and Ningxia, the mortality rate is on the rise. This is attributed to multiple factors, such as the unfavorable economic situation, poor access to health care in these regions, poor acceptance of testing, the large number of patients affected by the disease who are hiding their health status, and the presence of numerous opportunistic infections.

The number of newly diagnosed HIV-infected persons in the WHO European Region has risen by $22 \%$ in the last decade. The rate of newly diagnosed HIV infections has risen by $14 \%$ in the previous 10 years from 14.2 in 2009 to 16.2 in 2018 . This increase is primarily the result of the rise in the number of HIV-infected persons in Eastern Europe. The comparison of the number of new diagnoses with the estimated number of new HIV infections over the past decade has shown that more people contracted HIV than was diagnosed, which indicates that the number of undiagnosed HIV-infected persons in the region is rising [13].

In Serbia, in the 11-year observation period, a significant rise in the incidence of AIDS amounting to 4.9\% per year occurred in men, while in women a significant decline of $12.2 \%$ per year was registered. A study from 2017, which followed the trend of AIDS in Italy from 1999 to 2014 , could provide explanations for the rise in men contracting the disease. It was noted that men are more frequently unaware of being infected, which is why they begin treatment later. The study offers several potential explanations. Firstly, women are more often offered testing, for instance during pregnancy. Secondly, it is possible 
iz Španije, gde je 56\% testiranih bilo ženskog pola, što je u skladu sa preporukama za prenatalno testiranje [11]. U Srbiji, najveći porast uzrasno-specifičnih stopa incidencije kod muškaraca bio je u uzrastu 50 - 59 godina, i to $19,8 \%$ godišnje. I u Italiji je uočeno da je veća verovatnoća da se osobe uzrasta 50 i više godina kasno testiraju, u poređenju sa osobama uzrasta 35 - 49 godina [14]. Moguće je da su starije osobe manje svesne rizika od inficiranja HIV-om, s obzirom da su preventivne mere i usluge prevashodno usmerene ka mlađoj populaciji. Pored toga, socijalna stigma i diskriminacija izraženije su kod starijih, što stvara barijeru ka testiranju na HIV, tako da se neke bolesti koje se javljaju kod starijih ne prepoznaju kao bolesti indikativne za AIDS, što može dovesti do kasnijeg postavljanja dijagnoze $[14,15]$.

U Srbiji su u periodu 2007 - 2017. godine stope mortaliteta od AIDS-a kod muškaraca bile stabilne, dok je kod žena zabeležen značajan pad od 13,9\%. Kod žena se pad beleži u uzrastu 40 - 49 godina od $25,8 \%$. Od 1997. godine visokoaktivna antiretrovirusna terapija (engl. Highly Active Antiretroviral Therapy - HAART) dostupna je i besplatna u Republici Srbiji, tj. svi troškovi lečenja idu na teret Republičkog fonda za zdravstveno osiguranje za sve zdravstvene osiguranike kojima je lečenje indikovano. U Alžiru je, od uvođenja HAART-a 1998. godine, došlo do značajnog pada stope mortaliteta od AIDS-a. Procenat osoba inficiranih HIV-om koje su bile na terapiji je rastao, da bi u 2010. godini bio najviši (84\%). Stope mortaliteta su se sa 200,2 , pre uvođenja $H A A R T-a$, spustile na vrednost od 91,4 na 100.000 . Od 2003. godine stopa mortaliteta se, prema joinpoint analizi, smanjila za 66,1\% godišnje, da bi nakon 2006. došlo do porasta [16].

U studiji koja je ispitivala trend prijema u bolnicu, ponovnog prijema, kao i smrtnost inficiranih HIV-om u periodu 1993 - 2013, u univerzitetskoj bolnici na severozapadu Španije, došlo je do pada mortaliteta od bolesti koje su u vezi sa AIDS-om od 49\% [17]. U Brazilu se u periodu 2000 - 2011. beleži značajan pad stopa mortaliteta od tuberkuloze kod osoba sa HIV/AIDS-om od $1,7 \%$ godišnje, sa značajnim regionalnim varijacijama. Pad je značajan za muškarace $(-2,4 \%)$, dok je trend stabilan za žene. Pad je značajan za uzrasne grupe 20 - 29 i 30 - 39 godina. U starijim uzrastima ( 50 - 59, 60 - 69, 70 - 79 godina) beleži se značajan rastući trend mortaliteta. Mortalitet u pedijatrijskim i mlađim uzrastima, kao i za uzrast 40 - 49 godina ostao je stabilan tokom perioda ispitivanja [18].

$\mathrm{U}$ Srbiji je u posmatranom vremenskom periodu najčešći način transmisije novodijagnostikovane HIV infekcije zabeležen među MSM populacijom (69\% inficiranih). U posmatranom periodu, među MSM that women more often access healthcare than men [14]. This is also supported by data from Spain, where $56 \%$ of those tested were female, which is in keeping with recommendations for prenatal testing [11]. In Serbia, the greatest rise in age-specific incidence rates in men was in the age group of 50 to 59 years, amounting to $19.8 \%$ per year. In Italy, also, it was established that it was more probable for people over 50 years to get tested late, as compared to people aged between 35 and 49 years [14]. It is possible that older persons are less aware of the risk of being infected with HIV, since preventive measures and services are primarily directed towards the younger population. Also, social stigma and discrimination are more pronounced in older people, thus creating a barrier towards HIV testing, which is why certain diseases occurring in older patients are not recognized as indicative of AIDS, which can lead to later diagnosis $[14,15]$.

In Serbia, in the period between 2007 and 2017, AIDS-related mortality rates in men were stable, while in women, a significant decline of $13.9 \%$ was registered. In women, the decline registered in the age group of $40-49$ years was $25.8 \%$. Since 1997 , highly active antiretroviral therapy (HAART) has been available and free in the Republic of Serbia, i.e. all costs of treatment are charged to the Health Insurance Fund of the Republic of Serbia for all health insurance beneficiaries indicated for treatment. In Algeria, after the introduction of HAART, in 1998, a significant decrease in AIDS-related mortality occurred. The percentage of HIV-infected persons on therapy rose, reaching the highest value in 2010 (84\%). Mortality rates dropped from 200.2, before the introduction of HAART, to 91.4, per 100,000 . As of 2003 , the mortality rate, according to the joinpoint analysis, decreased by $66.1 \%$ per year, only to start rising after 2006 [16].

In a study testing the trend of hospital admission, readmission, and the mortality of HIV infected persons, in the period between 1993 and 2013, at a university clinic in North-West Spain, a decrease of $49 \%$ in mortality from AIDS-related diseases was registered [17]. In Brazil, in the period between 2000 and 2011, a significant drop of $1.7 \%$ per year in tuberculosis mortality rates was registered in persons with HIV/AIDS, with significant regional variations. The drop was significant for men $(-2.4 \%)$, while the trend was stable for women. The decrease was significant for the age groups of $20-29$ and 30 - 39 years. In the older age groups ( $50-59,60$ $-69,70-79)$ a significant rising mortality trend was registered. Mortality in pediatric and younger adult age groups, as well as for the age group of $40-49$ years remained stable during the observation period [18].

In Serbia, during the observation period, the most frequent mode of transmission of newly diagnosed HIV infection was noted in the MSM population (69\% of infected 
populacijom registruje se rastući trend novodijagnostikovanih muškaraca pozitivnih na HIV, dok se kod injektirajućih korisnika droga zapaža pad. Kod žena je, u posmatranom periodu, dominantan put prenosa bio nezaštićen heteroseksualni odnos (75,7\%). MSM populacija čini više od polovine novodijagnostikovanih osoba inficiranih HIV-om u zapadnoj i centralnoj Evropi, kojoj pripada i Srbija. Heteroseksualni kontakt (72\%) i konzumiranje droga injektiranjem (23\%) i dalje su glavni put prenošenja HIV-a u istočnoj Evropi [13].

Zabrinjava podatak iz Italije da je kod skoro dve trećine obolelih od AIDS-a, koji su se inficirali seksualnim kontaktom, kasno postavljena dijagnoza. Posebno visok rizik za kasnu dijagnozu imali su heteroseksualci, u poređenju sa injektirajućim korisnicima droge (IKD). Pretpostavlja se da programi prevencije nedovoljno pažnje posvećuju pojedincima koji imaju nisku svest o rizičnom seksualnom ponašanju i, na taj način, povećavaju verovatnoću zakasnelog testiranja na HIV [14].

Planirani ciljevi globalne strategije UNAIDS-a "90-90-90", do ovog trenutka nisu dostignuti. U svetu je u 2018. godini bilo 79\% osoba koje su živele sa HIV-om i koje su znale svoj pozitivan status, $62 \%$ osoba koje su znale svoj status bilo je na ARV terapiji, a $53 \%$ ljudi na ARV terapiji imalo je supresiju virusa. Procenjuje se da je u Srbiji krajem 2018. godine 3.000 osoba živelo sa HIV-om, od kojih je 2.597 (86,6\%) znalo svoj pozitivan status na HIV, dok je $72,5 \%$ dijagnostikovanih osoba inficiranih HIV-om bilo na ARV terapiji. I nakon 2020. godine ciljevi "90-90-90" ostaju najvažniji, signalizirajući da su potrebna dodatna ulaganja u testiranja na HIV i programe lečenja, kako bi se do 2030. okončala epidemija AIDS-a.

Ograničavajući faktor u našem istraživanju jeste činjenica da se u Srbiji, kao i u drugim zemljama sveta, registruju samo novodijagnostikovane osobe inficirane HIV-om pri čemu se ne zna koliko dugo imaju infekciju, odnosno kada su inficirane. Trend novodijagnostikovanih slučajeva HIV infekcije je uslovljen time u kom stadijumu infekcije se osobe dijagnostikuju, kao i u kom obimu se testiraju osobe pod povećanim rizikom za sticanje HIV infekcije, tako da ne reflektuje incidenciju HIV infekcije u populaciji, a takođe ne reprezentuje ni ukupnu prevalenciju HIV infekcije. Samim tim, ne može se jasno razlučiti da li je porast registrovanja novodijagnostikovanih osoba inficiranih HIV-om posledica povećanja broja novoinficiranih, ili opsežnijih testiranja, posebno u ključnim populacijama pod povećanim rizikom. Najnovije preporuke SZO obavezuju i Srbiju da preduzme mere koje će obezbediti prvi i najvažniji korak - a to je, širok pristup uslugama dobrovoljnog poverljivog savetovanja i testiranja na HIV, uz persons). In the observation period, a rising trend of newly diagnosed HIV positive men was registered in the MSM population, while a decline was registered amongst the population of injection drug users. In women, during the observation period, the dominant pathway of transmission was unprotected sexual intercourse $(75.7 \%)$. The MSM population constituted more than half of newly diagnosed HIV-infected persons in Western and Central Europe, which Serbia is a part of. Heterosexual intercourse (72\%) and injection drug abuse (23\%) remained the main pathways of HIV transmission in Eastern Europe [13].

The data from Italy indicating that almost two thirds of AIDS patients, who had become infected through sexual intercourse, were diagnosed late, is alarming. Heterosexuals had a particularly high risk of late diagnosis, as compared to injection drug users (IDUs). The assumption is that prevention programs do not pay enough attention to individuals with a low level of awareness regarding risky sexual behavior and, in that way, the probability of late HIV testing is increased [14].

Planned goals of the global UNAIDS 90-90-90 strategy have not as yet been achieved. Globally, in 2018, there were $79 \%$ of people living with HIV who were aware of their HIV positive status, $62 \%$ of people aware of their HIV positive status were on ARV therapy, and $53 \%$ of people on ARV therapy had viral suppression. It is estimated that, in Serbia, at the end of 2018, 3,000 persons were living with HIV, 2,597 (86.6\%) of whom were aware of their HIV positive status, while $72.5 \%$ of diagnosed HIV-infected persons were on ARV therapy. Even after 2020, the 90-90-90 goals remain of utmost importance, indicating that additional efforts and investments need to be made in HIV testing and treatment programs, in order to end the AIDS epidemic by 2030.

A limiting factor in this study is the fact that in Serbia, just like in other countries in the world, newly diagnosed HIV-infected persons are only registered, without any definite knowledge as to how long the patients have been infected, i.e. when the infection was contracted. The trend of newly diagnosed cases of HIV infection depends on the stadium of the infection that persons are diagnosed in, as well as on the scope of testing for persons at increased risk of HIV infection; thus it does not reflect HIV infection incidence in the population, nor does it represent the overall prevalence of the HIV infection. Consequently, it is not clear whether the rise in the number of newly diagnosed HIV-infected persons is the result of an increase in the number of newly infected persons, or the result of more comprehensive testing, especially amongst key populations, which are at increased risk. The latest WHO recommendations require of Serbia, as well, to take such steps that would enable the first, most important one, and that is broad access to voluntary confidential counselling services and HIV testing, with 
paralelno smanjivanje stigme i diskriminacije za osobe inficirane HIV-om, kao i uspešno sprečavanje prenošenja HIV infekcije, posebno u ključnim populacijama u visokom riziku za HIV.

\section{ZAKLJUČAK}

Za posmatrani period od 2007. do 2017. godine u Srbiji utvrđena je znatno veća stopa novodijagnostikovanih osoba inficiranih HIV-om kod muškaraca nego kod žena. Pad oboljevanja i umiranja od AIDS-a nije istovremeno praćen i smanjenjem broja novodijagnostikovanih osoba inficiranih HIV-om, pa uz produžen životni vek raste i ukupan broj osoba koje žive $s$ HIV-om, dok udeo osoba koje ne znaju svoj pozitivan status na HIV predstavlja rizik za dalju transmisiju infekcije. Javnozdravstvene mere prvenstveno treba da budu usmerene na prevenciju nastanka infekcije. Potrebno je dalje raditi na unapređenju preventivnih mera, posebno edukaciji mladih o putevima prenošenja i rizicima, kao i na ranom otkrivanju osoba inficiranih HIV-om i pravovremenom lečenju. Važno je povećati broj savetovanih i testiranih osoba iz ključnih populacija pod povećanim rizikom za HIV. Rano dijagnostikovanje HIV infekcije i pravovremena terapija doprinose smanjivanju transmisije infekcije na osetljivu populaciju.

Zahvalnica: Ovaj rad je finansiran sredstvima projekta br. 175042 Ministarstva prosvete, nauke i tehnološkog razvoja Republike Srbije.

Sukob interesa: Nije prijavljen.

\section{LITERATURA / REFERENCES}

1. UNAIDS. 90-90-90: An ambitious treatment target to help end the AIDS epidemic [Internet]. Geneva, Switzerland: UNAIDS; 2014. [citirano jul 2020.]. Dostupno na: http://www.unaids.org/en/resources/documents/2014/90-90-90.

2. UNAIDS. UNAIDS data 2019. Joint United Nations Programme on HIV/AIDS [Internet]. Geneva, Switzerland: UNAIDS; 2019. [citirano jul 2020.]. Dostupno na: https:// www.unaids.org/sites/default/files/media_asset/2019-UNAIDS-data_en.pdf

3. Institut za javno zdravlje „Dr Milan Jovanović Batut”. Izveštaj o zaraznim bolestima u Republici Srbiji za 2018. godinu [Internet]. Beograd, Republika Srbija: Institut za javno zdravlje „Dr Milan Jovanović Batut”; 2019. [citirano jul 2020.]. Dostupno na: http://www.batut.org.rs/index.php?content=1997

4. Institut za javno zdravlje „Dr Milan Jovanović Batut”. Izveštaji o zaraznim bolestima u Republici Srbiji (2007-2017. godina). Beograd, Republika Srbija: Institut za javno zdravlje „Dr Milan Jovanović Batut”. 2007-2017. [citirano jul 2020.]. Dostupno na: http://www.batut.org.rs/index.php?category_id=140

5. Segi M. Cancer mortality for selected sites in 24 countries (1950-57). Sendai, Japan: Department of Public Health, Tohoku University of Medicine; 1960.

6. Kim HJ, Fay MP, Feuer EJ, Midthune DN. Permutation tests for joinpoint regression with applications to cancer rates. Stat Med. 2000; 19(3):335-51.

7. Fong Y. Fast Bootstrap Confidence Intervals for Continuous Threshold Linear Regression. J Comput Graph Stat. 2019; 28(2):466-70. parallel destigmatization and removal of discrimination towards people infected with HIV, as well as effective prevention of HIV infection transmission, especially in key populations at high risk of HIV.

\section{CONCLUSION}

For the observation period from 2007 to 2017, in Serbia, a significantly higher rate of newly diagnosed HIV-infected persons was registered for men than for women. The decline in the number of patients developing AIDS and in AIDS-related mortality was not simultaneously followed by a decrease in the number of newly diagnosed HIV-infected persons, which is why, with a prolonged life span, the total number of persons living with HIV is increasing, while the portion of people unaware of their HIV positive status represents a risk factor for further infection transmission. Public health measures need to primarily be directed towards the prevention of infection. It is necessary to work further on improving preventive measures, especially on educating the young population on the pathways of transmission and the risks, as well as on early detection of HIV-infected persons and timely treatment. It is important to increase the number of counselled and tested persons in the key populations, who are at a higher risk of HIV infection. Early diagnosis of the HIV infection and timely treatment contribute to the decrease in infection transmission in vulnerable populations.

Acknowledgements: This paper was funded by project No. 175042 of the Ministry of Education, Science and Technological Development of the Republic of Serbia.

Conflict of interest: None declared.

8. Kim H-J, Fay MP, Yu B, Barrett MJ, Feuer EJ. Comparability of segmented line regression models. Biometrics. 2004; 60(4):1005-14.

9. Felicia A. Trends of HIV/AIDS Phenomenon Dynamics in Romania from 20172027. Iran J Public Health. 2019; 48(10):1903-9.

10. Diez M, Bleda MJ, Varela JR, Ordonana J, Azpiri MA, Vall M, et al. Trends in HIV testing, prevalence among first-time testers, and incidence in most-at-risk populations in Spain: the EPI-VIH Study, 2000 to 2009. Euro Surveill. 2014; 19(47):20971.

11. Mena A, Moldes L, Meijide H, Cañizares A, Castro-Iglesias A, Delgado M, et al. Seroprevalence of HCV and HIV infections by year of birth in Spain: impact of US CDC and USPSTF recommendations for HCV and HIV testing. PLOS ONE. 2014; 9(12): e113062.

12. Li M, Shen Y, Jiang X, Li Q, Zhou X, Lu H. Clinical epidemiology of HIV/AIDS in China from 2004-2011. Biosci Trends. 2014; 8(1):52-8.

13. European Centre for Disease Prevention and Control/WHO Regional Office for Europe. HIV/AIDS surveillance in Europe 2019 - 2018 data. Stockholm, Sweden: ECDC; 2019. [citirano jul 2020.]. Dostupno na: https://www.ecdc.europa. eu/en/publications-data/hivaids-surveillance-europe-2019-2018-data

14. Taborelli M, Virdone S, Camoni L, Regine V, Zucchetto A, Frova L, et al. The persistent problem of late HIV diagnosis in people with AIDS: a population-based study in Italy, 1999-2013. Public Health. 2017; 142:39-45. 
15. Emlet CA. "You're awfully old to have this disease": experiences of stigma and ageism in adults 50 years and older living with HIV/AIDS. Gerontologist. 2006; 46(6):781-90.

16. Chaabna K, Newton R, Vanhems P, Laouar M, Forman D, Boudiaf Z, et al. Cancer incidence and all-cause mortality in HIV-positive patients in Northeastern Algeria before and during the era of highly active antiretroviral therapy. J Cancer Res Ther. 2016; 12(2):576-81.
17. Meijide H, Mena Á, Rodríguez-0sorio I, Pértega S, Castro-Iglesias Á, Rodríguez-Martínez $G$, et al. Trends in hospital admissions, re-admissions, and in-hospital mortality among HIV-infected patients between 1993 and 2013: Impact of hepatitis C co-infection. Enferm Infecc Microbiol Clin. 2017; 35(1):20-6.

18. Lima M da S, Martins-Melo FR, Heukelbach J, Alencar CH, Boigny RN, Ramos AN. Mortality related to tuberculosis-HIV/AIDS co-infection in Brazil, 20002011: epidemiological patterns and time trends. Cad Saude Publica. 2016; 32(10): e00026715. 